\title{
Negative correlation between age of subjects and length of the appendix in Bangladeshi males
}

Sheikh Muhammad Abu Bakar', Manjare Shamim², Gazi Mahabubul Alam³, Muhammad Sarwar

1 Faculty of Medicine, University of Malaya, Kuala Lumpur, Malaysia

2Faculty of Basic Medical Science, Bangabandhu Sheikh Mujib Medical University (BSMMU), Dhaka, Bangladesh

${ }^{3}$ Academic Performance Enhancement Unit, University of Malaya, Jalan Panati

Baharu, Kuala Lumpur, Malaysia

${ }^{4} \mathrm{GM}$ College of Science and Technology, Faisalabad, Pakistan

Submitted: 1 December 2012

Accepted: 2 January 2013

Arch Med Sci 2013; 9, 1: 55-67

DOI: 10.5114 /aoms.2013.33349

Copyright (c) 2013 Termedia \& Banach

\section{Abstract}

Introduction: The anatomy of the vermiform appendix shows variations in its macroscopic dimensions some of which have potential to influence the clinical aspects of the appendix. Anatomical studies on the appendix using people in Bangladesh as a sample are limited and fall short of producing any standardized anthropometric data. This study is predominantly a cross-sectional observational study which also uses some statistical analysis to understand the relationships amongst variables.

Material and methods: Fifty-six adult male postmortem appendices and adnexa were examined for macroscopic features. Possible interrelationships among the variables were assessed through statistical analysis. The age of the samples ranged from 18 to 67 years. The most common position of the appendix was retrocolic $(53.57 \%)$ followed by pelvic $(30.35 \%)$, postileal $(12.5 \%)$, and subcaecal (3.5\%).

Results: In most cases $(62.5 \%)$ the mesoappendix did not reach the tip of the appendix. The appendicular length varied from $6.00 \mathrm{~cm}$ to $16.30 \mathrm{~cm}$ with mean ( \pm SD) and median value of $10.21 \pm 2.50 \mathrm{~cm}$ and $10.00 \mathrm{~cm}$ respectively. The base of the appendix was 1.90 to $3.80 \mathrm{~cm}$ away from the ileocaecal junction. The other macroscopic measurements of the appendix were taken at the base, at the midzone and at the tip of the appendix and the mean of the three measurements was considered as the overall value. Thus, the overall external diameter varied between $0.32 \mathrm{~cm}$ and $0.83 \mathrm{~cm}$. Assessment of possible correlations amongst different variables revealed a significant negative correlation between the age of the subjects and the length of the appendix.

Conclusions: The data of the present study may provide a baseline along with some previous data in the standardization of the anthropometric information regarding the vermiform appendix of Bangladeshi males.

Key words: vermiform appendix, cross-sectional observational study, adult males, Bangladesh.

\section{Introduction}

It is generally believed that the human body and its different parts and organs show variations according to age, sex, race and other relevant factors [1]. However, variations can also be observed even within the same age, sex and race [2-5]. Particularly, Stein and Rowe [2] point out that "race"

\author{
Corresponding author: \\ Muhammad Sarwar \\ GM College for Science \\ and Technology \\ 24 Gulshani Madina \\ 38090 Faisalabad \\ Pakistan \\ Phone: +92.321.425.8888 \\ E-mail: sarwarm@hotmail.com
}


is a man-made social concept, which may not always be necessarily connected with the biological concept. Stein and Rowe [2] are confident that there has been so much admixture and variability in the human gene pool that dividing the species into a finite number of "races" makes no sense. Hence, they add, various samples of people from different regions of the world do differ statistically in some anatomical and genetic characteristics. Variation is relatively frequent, so Moore [4], cited by Sanudo et al. [3], has described the meaning of "normal" as "within the normal range of variation". Therefore, different populations require their own standards of measurements and other characteristics of organs which can be considered as normal (i.e. the majority of the population). According to Tobias, cited by Moore [4], variations collected in a population cannot be assumed to apply to members of another population.

Likewise, Bangladesh is a country where the vast majority of the population (i.e., Bengali) are different from the so-called White, Black, and Mongoloid races. Nevertheless, Bengalis also differ in many ways from the other ethnic groups. Theory tries to establish a relation in histology between mankind and animals [5, 6] and ample studies have been done on the issue: cadaver, apparatus system, histology of animal and humans, morpho-anatomical issues, anatomy and histology of the vomeronasal organ $[7,8]$. In particular, Darwin asserts that the human being is the result of evolutionary change of apes. However, reality confirms that a person belonging to an ethnic group of a distinctly Dravidian origin and one belonging to a group of clearly Aryan origin can usually be distinguished, such as from a Bengali individual easily. However, a person belonging to an ethnic group of a distinctly Dravidian origin and one belonging to a group of a clearly Aryan origin can usually be distinguished, such as from a Bengali individual easily. In addition to variations in the macroscopic dimensions, there are possibilities of difference in other features, especially at microscopic and molecular levels. These visible and 'invisible' variations, if established, are bound to have tremendous anthropologic, forensic as well as clinical implications. Given the nature of these factors, this study was conducted to explore the possible correlation between the age of the subjects and the length of the appendix using males in Bangladesh as a sample.

\section{Global discourses on research issue}

The vermiform appendix of the human is a significant aspirant for probing into the problem of variation. Its length exposes the variability. It can vary from less than an inch to over a foot, being the longest in childhood and gradually shrinking throughout adult life [1, 4]. In addition, McCabe also regarded it as a vestigial organ or as an organ of "obscure function" [9]. It has also been viewed as a "highly specialized, well-differentiated organ apparently developed to the maximum in its specialization in man" [10]. In Current Medical Diagnosis and Treatment [11], appendicitis has been considered as "the most common abdominal surgical emergency, affecting approximately $10 \%$ of the population". Young adults face the problems of appendicitis more than the children or elderly, which has been attributed to the changes in its luminal diameter with age. Experts' opinions confirm that different positions of the appendix are related to the features specified and course of acute appendicitis [12].

A number of 'typical' presentations of appendicitis have also been attributed to the variability in the position of the appendix [11]. Thus, in addition to the anthropometric values, studies on the anatomy of the human appendix in specific populations have clinical implications. In order to understand possible relationships amongst its various anatomical features, fewer studies been conducted on the anatomy of the vermiform appendix using people in Bangladesh as samples. However, an in-depth study to explore especially the correlation between the age of the subjects and the length is yet to be conducted.

The appendix is significantly variable in its position in the abdomen. Wakeley [13] described six different positions that have been considered as 'conventional'. These are: anterior or pre-ileal, 'splenic' or post-ileal, pelvic, subcaecal, post-caecal or retrocolic and ectopic. Of six, five positions were later divided into two main groups by Maisel [14], cited by Buschard and Kjaeldgaard [15]. One of them is an 'anterior position' comprising the ileal and pelvic appendices and the other is a 'posterior position' comprising the subcaecal and retrocaecal appendices. Russell et al. [16], in regard to Gray's Anatomy, have mentioned the following positions: retrocaecal, retrocolic (behind the caecum and lower ascending colon respectively) and pelvic or descending (when it hangs dependently over the pelvic brim, in close relation to the right uterine tube and ovary in females). However, the figure presented in Gray's Anatomy shows 'promontoric' and 'paracolic/precaecal' positions in addition to the five above positions (as shown in Figure 2 B). The above described variable position of the appendix reasonably represents the position of its body. On the other hand, Moore [4] considered that the base of the appendix is fairly constant. The anterior taenia is usually distinct and can be traced to the appendix, which guides the direction to its location in clinical practice. It is connected by a short meso-appendix to the lower part of the ileal mesentery. This fold is usually triangular, extending almost to the 
appendicular tip along the whole viscous. The lumen of the appendix may be widely patent in early childhood and is often particularly or completely obliterated in the later decades of life.

The study intends to standardize the different macroscopic variables of the vermiform appendix with adult males in Bangladesh. Furthermore, adding the value in an anthropological perspective, the findings of this study are expected to help in understanding the prevalence and nature of appendicular pathologies in the population by understanding the pathologic and histological mechanism with an irrespective statistical approach [1-4, 13-15, 17-19]. Since the various positions are important and dominant factors for appendicitis, this study mainly focuses on and explores the issue of the appendix's position in regards to the pre-ileal and post-ileal poses (as it may spread the infection of appendicitis more to the other sides of the abdomen; hence, surgeons can determine whether the appendicitis is severe by detecting the position of the appendix). In addition, the mesoappendix is another important site which indicates whether appendicitis is common. This study maps the appendicitis cases regarding whether mesoappendices occupy the full length of the appendix or they occupy two-thirds length of the appendix (i.e. due to the lack of blood supply to the un-occupied portion of the appendix).

Fulfilling the above aims, the following specific objectives were set for the study:

- Macroscopic study: to determine the frequency of different positions of the appendix in the abdomen, to determine the incidence of the mesoappendix reaching the tip of the appendix, to measure the macroscopic dimensions of the vermiform appendix: length as well as external diameter at three segmental levels (base, midzone and tip), to measure the distance between the base of the appendix and the ileocaecal junction.

- Regression analysis: to assess the possible relationships among different macroscopic variables of the appendix and their possible relationships with age.

\section{Material and methods}

The vermiform appendices along with the caecum, adjacent parts of the ascending colon and terminal ileum were collected from the morgue of the Department of Forensic Medicine of Dhaka Medical College. The study was carried out in the Department of Anatomy, Bangabandhu Sheikh Mujib Medical University, Dhaka, during the period of July 2006 to June 2007, and consent was taken from the authority of Dhaka Medical College Hospital to collect the appendices for study purposes.

Inclusion criteria for the subjects: adult by age (18 years and above), male by sex, Bangladeshi by nationality (and Bengali by ethnic group as far as identifiable by name, physical features and records).

Exclusion criteria for the specimens: any sign of decomposition, any injury to the appendix, caecum, proximal ascending colon or terminal ileum, inflammation of any of the above structures.

\section{Variables studied}

Age of the subjects - the subjects were adult by age -18 years and above.

Position - Position of the appendix (retrocaecal or retrocolic/pelvic/subcaecal/preileal/postileal/others), extension of the meso-appendix, distance between the base of the appendix and the ileo-caecal junction, length of the appendix, external diameter of the appendix (measured at three segmental levels: base, midzone and tip).

Relationships among different variables:

1. Relationship of the age of the subjects with different variables: with the length of the appendix and with the overall external diameter of the appendix.

2. Relationships among the variables: relationship of the length of the appendix with the distance between the base of the appendix and the ileocaecal junction, with the external diameter of the appendix at the base, at the midzone and at the tip with the overall external diameter of the appendix.

\section{Data collection methods for macroscopic study in-situ}

Before determining the position of the appendix, the approximate age of the subject was noted from the record book of the Department of Forensic Medicine of Dhaka Medical College, Dhaka, Bangladesh.

\section{Determination of the position of the appendix}

This part of the study was done in situ in the cadaver, before the organ was displaced by manipulation and dissected out from the right iliac fossa. The abdomen had already been opened by a long midline incision (for autopsy purposes). The flaps were reflected to get a good view of the abdominal cavity along with its contents. Then the taeniae coli of the caecum were identified. The three taeniae coli on the ascending colon and caecum converged at the base of the vermiform appendix merging into its longitudinal muscle coat. The anterior taenia coli were usually distinct and traceable to the base of the vermiform appendix. So, it acted as a guide to the appendix. Then the position of the appendix was studied in relation to the caecum, ascending colon and terminal ileum and the finding was noted (Figures 1, 2). 


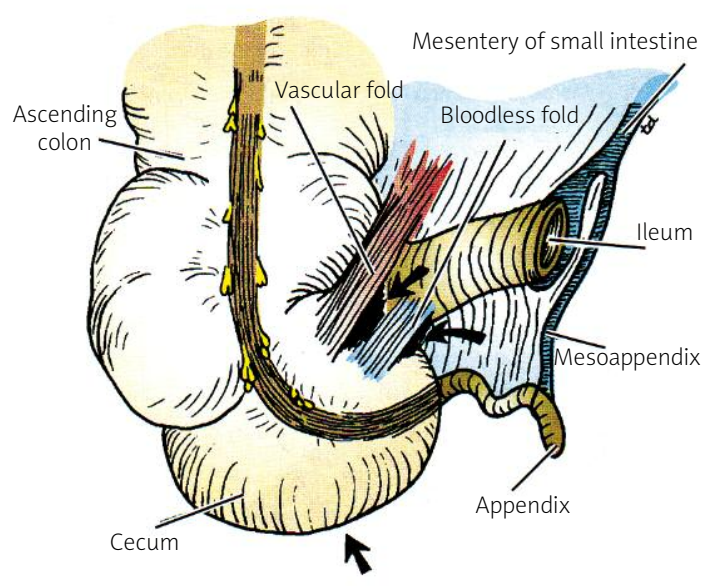

Figure 1. A semi-realistic figure of the vermiform appendix along with the meso-appendix, terminal ileum, caecum and the adjoining part of the ascending colon $[20,21]$

\section{Determination of the extension of the meso-appendix}

Also traced in-situ from the base of the appendix on the wall of the caecum towards the tip of the appendix to see whether it reached the tip.

\section{Collection of the specimen and preparation for the other macroscopic studies}

Firstly, the caecum and the proximal part of the ascending colon was mobilized by blunt dissection, using gloved fingers and the handle of a Black Pearl handle knife. About $10 \mathrm{~cm}$ to $12.5 \mathrm{~cm}$ from the caecum, the ascending colon was divided with a sharp knife in between two ligatures to prevent soiling of the dissection field by the spilled contents of the gut. The distal $10 \mathrm{~cm}$ to $12.5 \mathrm{~cm}$ of the ileum were similarly divided between two ligatures. Then with a pair of scissors, the mesentery was cut radially as far away from the intestinal border as possible. Afterward, the ligatures were removed from the specimen and the content of the bowel was emptied. After thorough cleaning with water, the specimen was labeled with a tag carrying an identification number and kept in normal saline.

\section{Methods of measuring the length and external diameter of the appendix}

The length was measured with a flexible measuring tape. One measurement was taken from the base to the tip of the appendix and another from the tip to the base. The mean of the two measurements was taken as the actual length (from base to tip) of the appendix and was expressed in centimeters (as shown in Figures $3 \mathrm{~A}$ and $3 \mathrm{~B}$ ).

The external diameter of the appendix was measured with the help of vernier calipers. At the

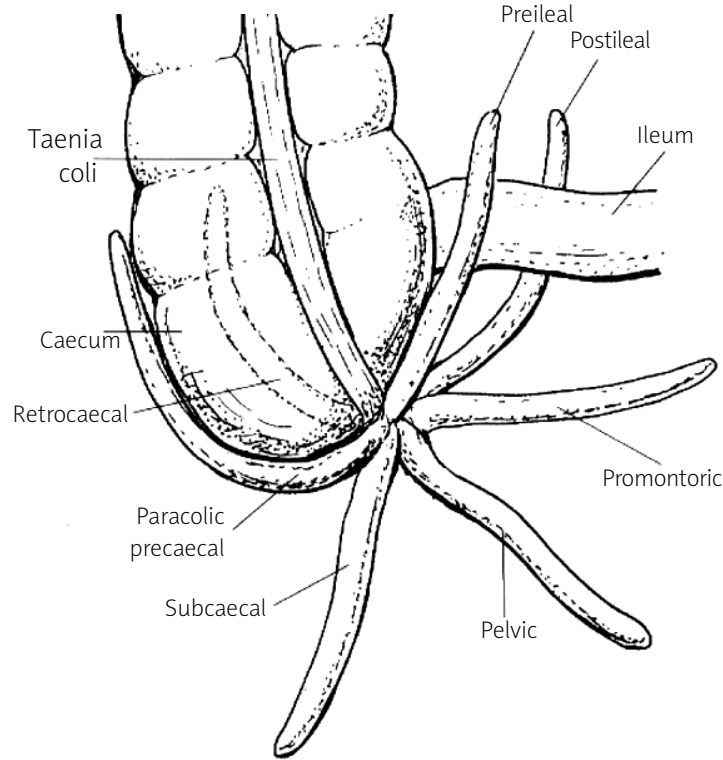

Figure 2. Common variations in the position of the vermiform appendix in Gray's Anatomy [21-23]. The same variations are shown in Buschard and Kjaeldgaard [15] as drawn according to Wakeley [13]

base, two measurements were taken, one measurement perpendicular to the other. The mean of the two measurements was taken as the actual external diameter at the base and was expressed in centimeters. For measuring two diameters at the tip, the point where the curved tip of the appendix met the rest of the organ was chosen. Two diameters of the midzone were measured at the midpoint between the base and the tip. Again, the mean of the two measured values was taken as the actual external diameter at the corresponding segmental level and was expressed in centimeters. Then the overall mean external diameter was calculated by averaging the values at the three segmental levels. The locations where the measurements were taken are shown in Figures $4 \mathrm{~A}$ and $4 \mathrm{~B}$.

\section{Method of measuring the distance between the base of the appendix and the ileocaecal junction}

This distance was measured with a flexible measuring tape. One measurement was taken from the base of the appendix to the ileocaecal junction and another measurement was taken from the ileocaecal junction to the base of the appendix. The mean of the two measurements was taken as the actual distance between the base of the appendix and ileocaecal junction and was expressed in centimeters (Figures $5 \mathrm{~A}$ and $5 \mathrm{~B}$ ).

\section{Age distribution of the subjects}

The approximate age of the subjects of the present study ranged from 18 years to 67 years. 

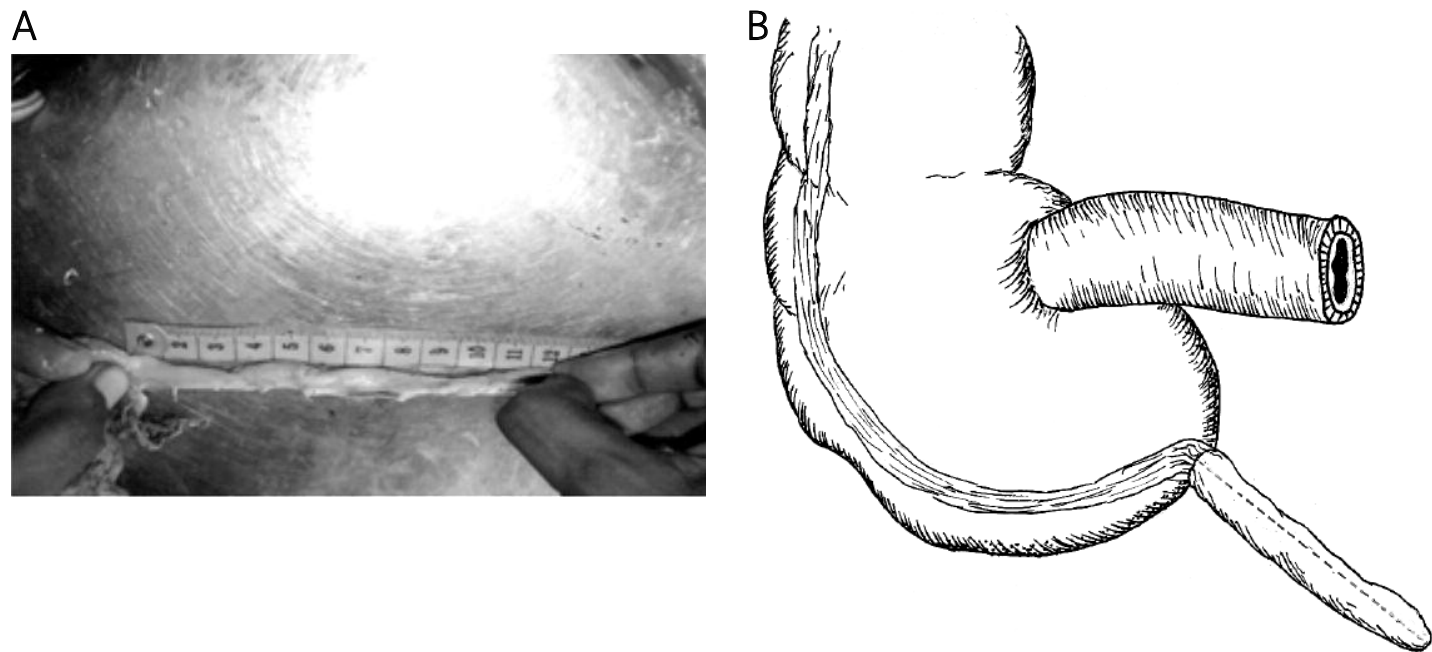

Figure 3. Method of measuring the length of the vermiform appendix. A-Photograph showing the use of the flexible measuring tape. B - Diagram showing the line connecting the middle of the base and that of the tip (red interrupted line) along which the length was measured

A

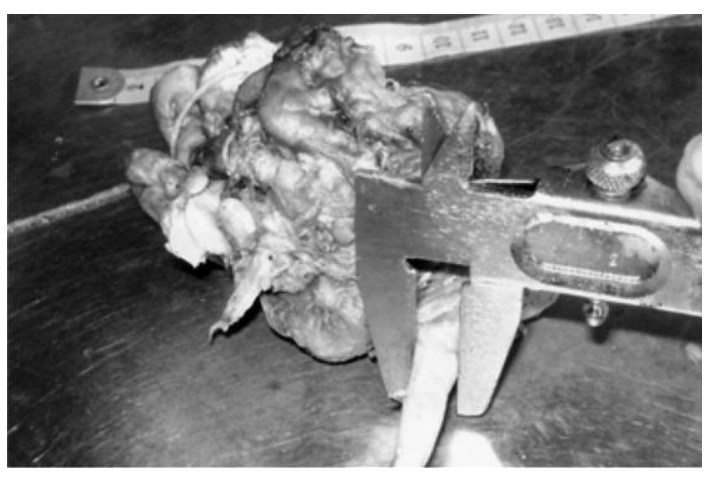

B

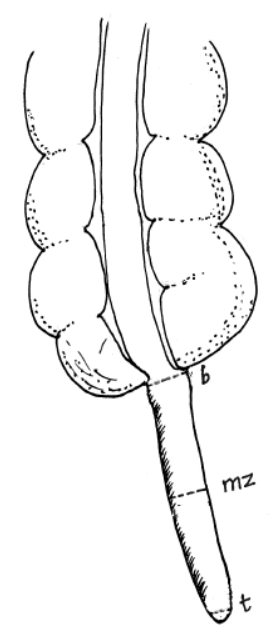

Figure 4. Method of measuring the external diameter of the vermiform appendix. A - Photograph showing the use of the vernier caliper. B - Diagram showing the lines along which the external diameter was measured at the base (b), at the midzone $(\mathrm{mz})$ and at the tip $(\mathrm{t})$

A

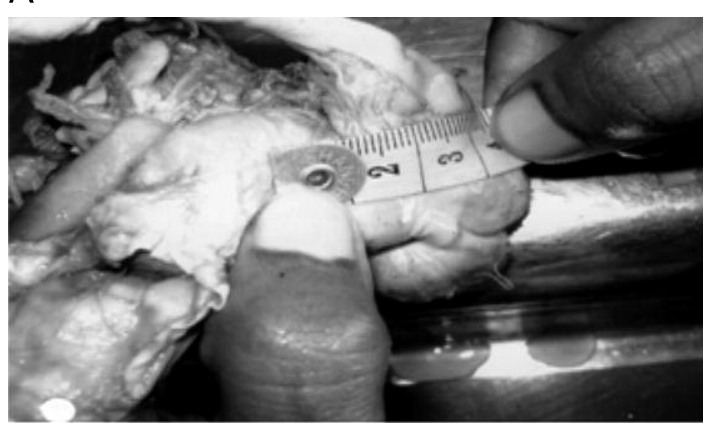

B

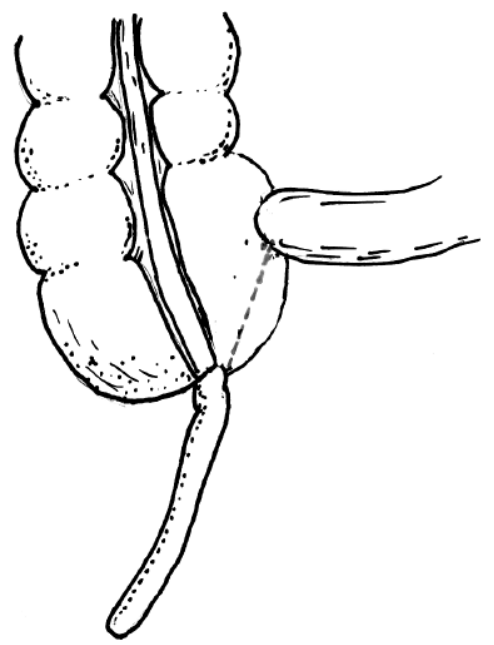

Figure 5. Method of measuring the distance between the base of the appendix and the ileo-caecal junction. A - Photograph showing the use of the flexible measuring tape. B - Diagram showing the line distance was measured 


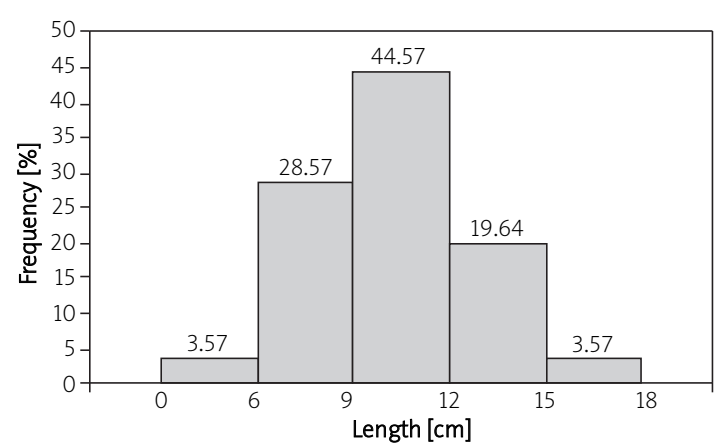

Figure 6. Histogram showing the frequency distribution of the length of the appendix $(n=56)$

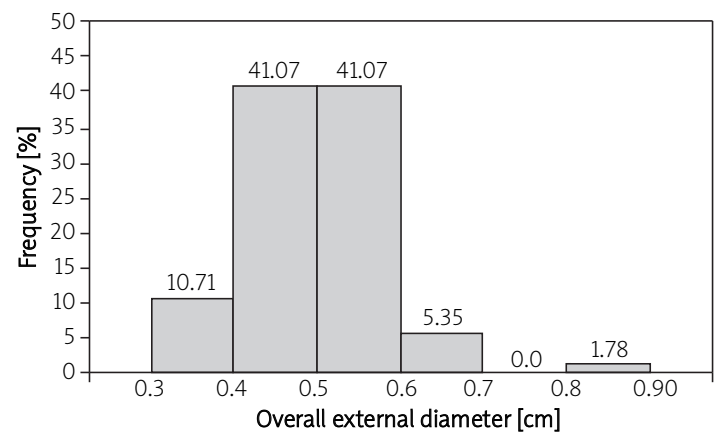

Figure 7. Histogram showing the frequency distribution of the overall external diameter of the appendix $(n=56)$

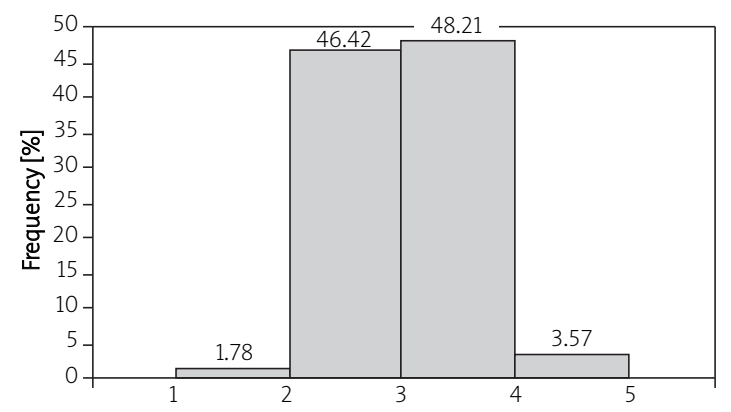

Distance between the base of the appendix and the ileo-caecal junction [cm]

Figure 8. Histogram showing the frequency distribution of the distance between the base of the appendix and the ileo-caecal junction $(n=56)$

Almost half of the subjects were aged between 21 and 40 years. Only 3 out of the 56 subjects were above 60 years of age.

\section{Results}

The macroscopic findings described below are those of 56 appendices (Table I). The position of the vermiform appendix varied considerably. The fre-
Table I. Best-fit curve data for the experimental group (A)

\begin{tabular}{|lc|}
\hline Variables & Frequency \\
\hline Position of the appendix: & $30(53.57 \%)$ \\
\hline Retrocaecal or retrocolic & $17(30.35 \%)$ \\
\hline Pelvic & $2(3.57 \%)$ \\
\hline Subcaecal & $0(0 \%)$ \\
\hline Pre-ileal & $7(12.5 \%)$ \\
\hline Others & $0(0 \%)$ \\
\hline Extension of the meso-appendix: & $21(37.5 \%)$ \\
\hline Reached the tip of the appendix & $35(62.5 \%)$ \\
\hline
\end{tabular}

quencies of these variations among the 56 specimens are shown in Table I. In more than half of the individuals, the position was retrocaecal or retrocolic. The next most common position was the pelvic position (about in one-third of the subjects) followed by the post-ileal and subcaecal positions respectively. The meso-appendix failed to reach the tip in the majority $(62.5 \%)$ of cases (Table I).The length of the appendix ranged from $6 \mathrm{~cm}$ to $16.3 \mathrm{~cm}$, as shown in Table II, more than $40 \%$ measuring between $9.00 \mathrm{~cm}$ and $11.99 \mathrm{~cm}$ (Figure 6).

\section{External diameter of the appendix}

The external diameter of the appendix ranged from $0.32 \mathrm{~cm}$ to $0.83 \mathrm{~cm}$, as shown in Table II. More than $80 \%$ of them measured between $0.40 \mathrm{~cm}$ and $0.59 \mathrm{~cm}$ (Figure 7).

\section{Distance between the base of the appendix and the ileo-caecal junction}

It varied from $1.9 \mathrm{~cm}$ to $3.8 \mathrm{~cm}$, as shown in Table II. In about $95 \%$ of the subjects, the distance varied between $2.00 \mathrm{~cm}$ and $3.99 \mathrm{~cm}$ (Figure 8).

\section{General considerations}

To avoid changes during presentation all macroscopic measurements were taken before fixation. In this study, 10\% formal saline rather than formalin was used as a fixative to minimize the shrinkage whatever it was.

\section{Relationships among different variables}

Possible relationships were assessed between selected pairs of variables rather than between all possible pairs of variables.

\section{Relationships of macroscopic variables with the age of the subject}

Both the length of the appendix (Figure 9) and its overall external diameter (Figure 10) showed 
Table II. Length and external diameter of the appendix and distance between the base of the appendix and the ileocaecal junction

\begin{tabular}{|llcc|}
\hline Variables & \multicolumn{2}{c|}{ Measurement } \\
\cline { 2 - 4 } & Range & Mean \pm SD & Median \\
\hline Length of the appendix $[\mathrm{cm}]$ & $6.00-16.30$ & $10.21 \pm 2.50$ & 10.00 \\
\hline $\begin{array}{l}\text { External diameter of the appendix }[\mathrm{cm}]: \\
\text { At the base }\end{array}$ & $0.37-0.94$ & $0.60 \pm 0.10$ & 0.64 \\
\hline At the midzone & $0.32-0.91$ & $0.53 \pm 0.10$ & 0.54 \\
\hline At the tip & $0.24-0.64$ & $0.32 \pm 0.05$ & 0.33 \\
\hline Overall & $0.32-0.83$ & $0.48 \pm 0.08$ & 0.49 \\
\hline $\begin{array}{l}\text { Distance between the base of the appendix } \\
\text { and the ileocaecal junction }[\mathrm{cm}]\end{array}$ & $1.90-3.80$ & $3.05 \pm 0.53$ & 3.00 \\
\hline
\end{tabular}

$N$ (no. of appendices) $=56$ for each variable

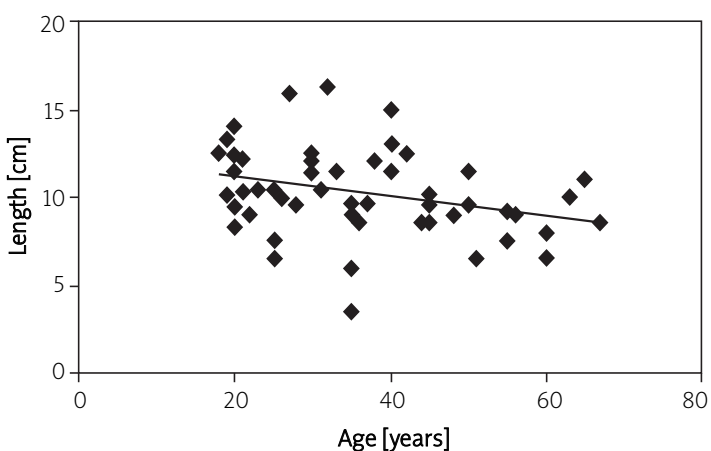

Figure 9. Scatter diagram with regression analysis showing significant negative correlation between the age of the subject and the length of the appendix $(r=0.303, p=0.023)$

a tendency towards a negative correlation with the age of the subject. However, only the correlation with the length reached a significant level.

\section{Relationships among the variables}

Tendencies of positive correlation were found between the length and the external diameter of the appendix at the base, at the midzone (Figure 11) as well as with the overall external diameter (Figure 12). However, none of these tendencies of correlation reached any statistically significant level. Almost no tendency of any correlation of the length with the external diameter was noted at the tip (Figure 11). The distance between the base of the appendix and the ileocaecal junction (Figure 13) showed a non-significant tendency towards a negative correlation with the length of the appendix.

\section{Discussion}

The discussion on the results of the present study has been prepared by comparing the results of several studies and descriptions by several

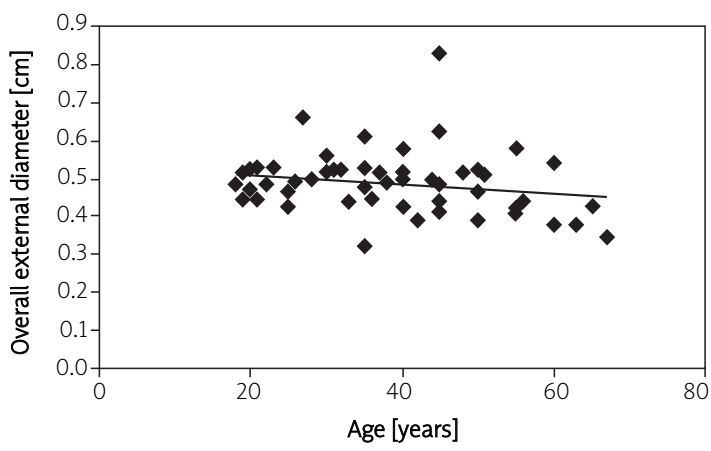

Figure 10. Scatter diagram with regression analysis showing non-significant negative correlation between the age of the subject and the overall external diameter of the appendix $(r=0.202, p=0.135)$

authors (Tables III and IV). The following are the details of the populations mentioned by those authors. Ajmani and Ajmani [32] worked on the appendices of 100 Indian cadavers from the Uttar Pradesh region. Andreou et al. [33] worked on the appendices of 71 male and 30 female post-mortem cases at Southampton General Hospital, Southampton, UK residents. The mean age of the patients was 69.4 years with the majority (80\%) being over 60 years of age. Buschard and Kjaeldgaard [15] worked on the appendices of 399 Danish people (141 autopsy materials from adults, 33 operational materials, 25 embryological materials, 200 X-ray materials) and 93 Czech autopsy cases. Chowdhury [24] worked on the appendices of 100 postmortem specimens of Bangladeshi people aged 5 to 70 years of whom 68 subjects were males and 32 were females. Rahman et al. [34] measured a total of 100 vermiform appendices of different age and sex and the findings were classified in four groups (up to 20 years, 21 to 35 years, 36 to 55 years and 56 to 70 years). The highest mean length of the vermiform appendix in group A was $9.17 \mathrm{~cm}$ and the lowest was $5.93 \mathrm{~cm}$ in group D. Collins [30] worked on 
A
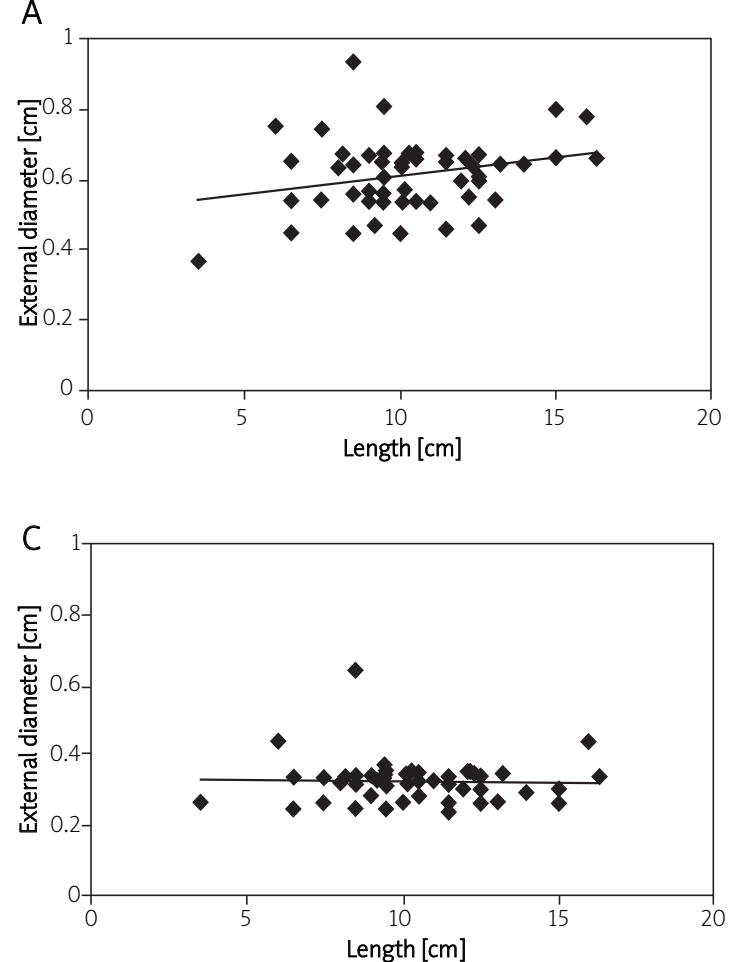

B

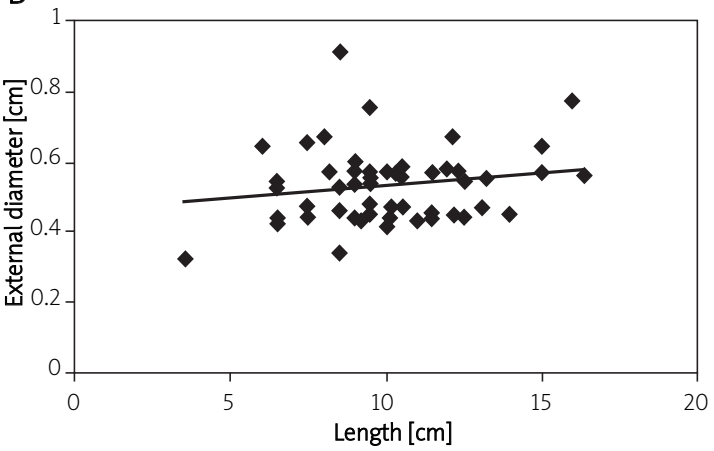

Figure 11. Scatter diagram with regression analysis showing non-significant positive correlation between the length and the external diameter of the appendix at the base $(A)(r=0.258 ; p=0.054)$ and at the midzone (B) $(r=0.174$; $p=0.199$ ). However, the $\mathrm{p}$ value for the correlation at the base is very close to 0.05. Almost no tendency of correlation is seen at the tip (C) $(r=0.027 ; p=0.845)$

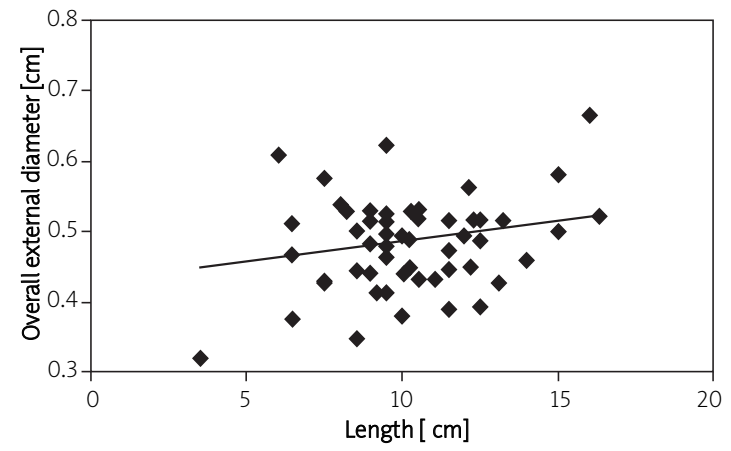

Figure 12. Scatter diagram with regression analysis showing non-significant positive correlation between the length and the overall external diameter of the vermiform appendix $(r=0.175$ and $p=0.197)$

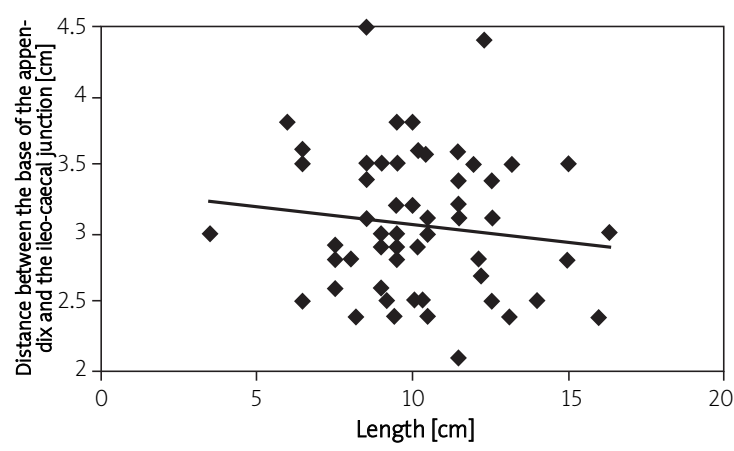

Figure 13. Scatter diagram with regression analysis showing non-significant negative correlation of the length of the appendix with the distance between the base of the appendix and the ileo-caecal junction $(r=0.043$ and $p=0.819)$

at the Gorgan Teaching Hospital, in Gorgan to the south-east of the Caspian Sea in the north of Iran. The patients belonged to two racial groups: 1) Native Fars group including 93 patients who live in this area; 2) Turkmen group including 24 patients who immigrated two centuries ago from central Asia. Also on the basis of age, the patients were grouped into: 1) adult group (aged 18 years and above), 2) child group (age < 18 years). 
Table III. Comparison of the findings/descriptions of various studies/literature: position of the appendix in different populations with those of the present study

\begin{tabular}{|c|c|c|c|c|c|}
\hline \multicolumn{2}{|l|}{ Reference } & \multirow[t]{2}{*}{ Population* } & \multirow{2}{*}{$\begin{array}{l}\text { No. of } \\
\text { subjects } †\end{array}$} & \multirow[t]{2}{*}{ Major positions } & \multirow[t]{2}{*}{ Frequency } \\
\hline Author(s) & $\begin{array}{l}\text { Year and } \\
\text { page no. }\end{array}$ & & & & \\
\hline Present study & 2007 & $\begin{array}{l}\text { Bangladeshi } \\
\text { Bengali adult male cadavers }\end{array}$ & 56 & $\begin{array}{l}\text { Retrocaecal and retrocolic } \\
\text { Pelvic }\end{array}$ & $\begin{array}{l}53.57 \% \\
30.35 \%\end{array}$ \\
\hline Chowdhury [24] & 1993 & $\begin{array}{l}\text { Bangladeshi cadavers } \\
\text { (aged } 5 \text { to } 70 \text { years) }\end{array}$ & $\begin{array}{l}\text { Males } 68 \\
\text { Females } 32\end{array}$ & $\begin{array}{l}\text { Retrocaecal and retrocolic } \\
\text { Pelvic } \\
\text { Retrocaecal and retrocolic } \\
\text { Pelvic }\end{array}$ & $\begin{array}{c}41 \% \\
18 \% \\
20 \% \\
9 \%\end{array}$ \\
\hline $\begin{array}{l}\text { Shah and Shah's } \\
\text { study cited by } \\
\text { Solanke [25] }\end{array}$ & 1945 & Indian cadavers & 405 & $\begin{array}{l}\text { Retrocaecal } \\
\text { Ileo-caecal }^{\ddagger} \\
\text { and pelvic }\end{array}$ & $\begin{array}{l}45.6 \% \\
\text { Next }\end{array}$ \\
\hline \multirow[t]{3}{*}{$\begin{array}{l}\text { Golalipour et al. } \\
\text { [26] }\end{array}$} & 2003 & Iranians (Northern): & Males 59 & $\begin{array}{l}\text { Retrocaecal } \\
\text { Pelvic }\end{array}$ & $\begin{array}{l}33.90 \% \\
33.90 \%\end{array}$ \\
\hline & & Native Fars & 93 & $\begin{array}{l}\text { Retrocaeca } \\
\text { Pelvic }\end{array}$ & $\begin{array}{l}29.03 \% \\
24.40 \%\end{array}$ \\
\hline & & Turkamans & 24 & $\begin{array}{l}\text { Retrocaecal } \\
\text { Pelvic }\end{array}$ & $\begin{array}{l}44.00 \% \\
29.16 \%\end{array}$ \\
\hline $\begin{array}{l}\text { Jewer's study } \\
\text { cited by Katzarski } \\
\text { and Dutta [27] }\end{array}$ & 1959 & UK residents & & Retrocaecal and retrocolic & Commonest \\
\hline $\begin{array}{l}\text { Buschard and } \\
\text { Kjaeldgaard [15] }\end{array}$ & 1973 & $\begin{array}{l}\text { Danish autopsy, operational, } \\
\text { embryological, X-ray cases } \\
\text { and Czech autopsy cases }\end{array}$ & 234 & $\begin{array}{l}\text { Osterior (retrocaecal and } \\
\text { Psubcaecal) }\end{array}$ & $\begin{array}{l}56.7 \% \text { and } \\
2.1 \%\end{array}$ \\
\hline Maisel [14] & 1960 & $\begin{array}{l}\text { Colored, Bantu (Negro) } \\
\text { and White adult cadavers } \\
\text { of South Africa }\end{array}$ & 300 & $\begin{array}{l}\text { Retrocaecal and retrocolic } \\
\text { Pelvic }\end{array}$ & $\begin{array}{c}26.7 \% \\
58 \%\end{array}$ \\
\hline $\begin{array}{l}\text { Archampong's study } \\
\text { cited by Katzarski } \\
\text { and Dutta [27] }\end{array}$ & y 1968 & Ghanaians & & Retrocaecal and retrocolic & Commonest \\
\hline $\begin{array}{l}\text { Katzarski and } \\
\text { Dutta [27] }\end{array}$ & 1971 & Ghanaian cadavers & $\begin{array}{l}\text { Males } 95 \\
\text { Females } 37\end{array}$ & $\begin{array}{l}\text { Postcaecal and retrocolic } \\
\text { Pelvic } \\
\text { Retroileal (postileal) }\end{array}$ & $\begin{array}{l}24.2 \% \\
43.2 \% \\
18.2 \%\end{array}$ \\
\hline Solanke [25] & 1970 & Nigerian children and adults & 125 & $\begin{array}{l}\text { Retrocaecal } \\
\text { Pelvic }\end{array}$ & $\begin{array}{l}38.4 \% \\
31.2 \%\end{array}$ \\
\hline $\begin{array}{l}\text { Katzarski et al. } \\
{[28]}\end{array}$ & 1979 & Zambian cadavers & $\begin{array}{l}\text { Males } 73 \\
\text { Females } 30\end{array}$ & $\begin{array}{l}\text { Retrocaecal } \\
\text { Pelvic } \\
\text { Retroileal (postileal) }\end{array}$ & $\begin{array}{l}20.3 \% \\
43.6 \% \\
19.4 \%\end{array}$ \\
\hline $\begin{array}{l}\text { Ndoye et al. } \\
{[29]}\end{array}$ & 2005 & Native cadavers & $\begin{array}{l}\text { Males } 62 \\
\text { Females } 18\end{array}$ & Pelvic & $51.2 \%$ \\
\hline $\begin{array}{l}\text { Peterson's study } \\
\text { cited by Maisel } \\
{[14]}\end{array}$ & 1934 & & 373 & $\begin{array}{l}\text { Retrocaecal and retrocolic } \\
\text { Pelvic } \\
\text { lleo-caecal }^{\ddagger}\end{array}$ & $\begin{array}{c}31 \% \\
42 \% \\
26.8 \%\end{array}$ \\
\hline Collins [30] & 1932 & & 4680 & $\begin{array}{l}\text { Retrocaecal } \\
\text { Pelvic }\end{array}$ & $\begin{array}{l}20.2 \% \\
78.5 \%\end{array}$ \\
\hline Wakeley [13] & 1933 & & 10000 & Post-caecal and retrocolic & $65.28 \%$ \\
\hline Borley [21] & $\begin{array}{l}2005, \\
\text { p. } 1889\end{array}$ & & & $\begin{array}{l}\text { Retrocaecal, retrocolic, } \\
\text { pelvic }\end{array}$ & Commonest \\
\hline Moore [4] & $\begin{array}{l}1992, \\
\text { p. } 205\end{array}$ & & & $\begin{array}{l}\text { Retrocaecal and retrocolic } \\
\text { Pelvic }\end{array}$ & $\begin{array}{l}64 \% \\
32 \%\end{array}$ \\
\hline $\begin{array}{l}\text { Lierts's study cited } \\
\text { by Maisel [14] }\end{array}$ & 1909 & & 2092 & $\begin{array}{l}\text { Retrocaecal and retrocolic } \\
\text { Pelvic }\end{array}$ & $\begin{array}{c}35 \% \\
42.1 \%\end{array}$ \\
\hline
\end{tabular}

*Only the adult populations or the populations where nothing about the age was known are presented here. TWhere results from both males and females were provided separately in the literature, only the results in the males are shown excepting those from Chowdhury [24], where combined results have been provided; this table shows the combined results for both males and females. ${ }^{\ddagger}$ Includes pre-ileal, splenic, iliac and promontoric positions 
Table IV. Comparison of the findings/descriptions of various studies/literature regarding some macroscopic variables of the appendix in different populations with those of the present study

\begin{tabular}{|c|c|c|c|c|c|}
\hline \multicolumn{2}{|l|}{ Reference } & \multirow[t]{2}{*}{ Population* } & \multirow{2}{*}{$\begin{array}{l}\text { No. of } \\
\text { subjectst }\end{array}$} & \multirow[t]{2}{*}{ Variable } & \multirow[t]{2}{*}{ Frequency ${ }^{\dagger}$} \\
\hline Author(s) & $\begin{array}{l}\text { Year and } \\
\text { page no. }\end{array}$ & & & & \\
\hline Present study & 2007 & $\begin{array}{l}\text { Bangladeshi Bengali adult } \\
\text { male cadavers }\end{array}$ & 56 & $\begin{array}{l}\text { Extension of meso-appendix } \\
\text { to the tip }\end{array}$ & $37 \%$ \\
\hline Solanke [25] & 1970 & $\begin{array}{l}\text { Nigerian: } \\
\text { Perinates } \\
\text { Children and adults }\end{array}$ & 78 & $\begin{array}{l}\text { Extension of meso-appendix } \\
\text { to the tip }\end{array}$ & $\begin{array}{l}88.5 \% \\
86.4 \%\end{array}$ \\
\hline $\begin{array}{l}\text { Golalipour } \\
\text { et al. [26] }\end{array}$ & 2003 & Iranians & 117 & $\begin{array}{l}\text { Extension of meso-appendix } \\
\text { to the tip }\end{array}$ & $34.2 \%$ \\
\hline $\begin{array}{l}\text { Kelynack's study } \\
\text { cited by Solanke [25] }\end{array}$ & 1893 & & & $\begin{array}{l}\text { Extension of meso-appendix } \\
\text { to the tip }\end{array}$ & $80 \%$ \\
\hline $\begin{array}{l}\text { Monks and Blake's } \\
\text { study cited by } \\
\text { Solanke [25] }\end{array}$ & 1902 & & 243 & $\begin{array}{l}\text { Extension of meso-appendix } \\
\text { to the tip }\end{array}$ & $64.6 \%$ \\
\hline Present study & 2007 & $\begin{array}{l}\text { Bangladeshi Bengali adult } \\
\text { male cadavers }\end{array}$ & 56 & $\begin{array}{l}\text { Distance between base of } \\
\text { appendix and ileo-caecal } \\
\text { junction }\end{array}$ & $\begin{array}{l}1.90-3.80 \\
(3.05) \mathrm{cm}\end{array}$ \\
\hline Ndoye et al. [29] & 2005 & Native cadavers & $\begin{array}{l}\text { Males } 62 \\
\text { Females } 18\end{array}$ & $\begin{array}{l}\text { Distance between base of } \\
\text { appendix and ileo-caecal } \\
\text { junction }\end{array}$ & $\begin{array}{l}1.50-4.00 \\
(2.42) \mathrm{cm}\end{array}$ \\
\hline Present study & 2007 & $\begin{array}{l}\text { Bangladeshi Bengali adult } \\
\text { male cadavers }\end{array}$ & 56 & Length of appendix & $\begin{array}{l}6.00-16.30 \\
(10.21) \mathrm{cm}\end{array}$ \\
\hline Chowdhury [24] & 1993 & $\begin{array}{l}\text { Bangladeshi cadavers } \\
\text { (aged } 5 \text { to } 70 \text { years) }\end{array}$ & $\begin{array}{l}\text { Males } 68 \\
\text { Females } 32\end{array}$ & Length of appendix & $\begin{array}{l}2-13(8.25) \mathrm{cm} \\
3-12(7.28) \mathrm{cm}\end{array}$ \\
\hline $\begin{array}{l}\text { Ajmani and } \\
\text { Ajmani [32] }\end{array}$ & 1983 & $\begin{array}{l}\text { Indian males } \\
\text { (Uttar Pradesh) }\end{array}$ & & Length of appendix & $(9.56) \mathrm{cm}$ \\
\hline $\begin{array}{l}\text { Katzarski and } \\
\text { Dutta [27] }\end{array}$ & 1971 & Ghanaian male cadavers & & Length of appendix & $4-8.7(10.1) \mathrm{cm}$ \\
\hline Solanke [25] & 1970 & Nigerian children and adults & $5 \quad 200$ & Length of appendix & (9.6) $\mathrm{cm}$ \\
\hline Katzarski et al. [28] & 1979 & Zambian male cadavers & 103 & Length of appendix & $3.5-23(12) \mathrm{cm}$ \\
\hline Collins [30] & 1932 & Negro and White patients & & Length of appendix & $(8.21) \mathrm{cm}$ \\
\hline Borley [21] & 05, p. 1189 & & & Length of appendix & $2-20 \mathrm{~cm}$ \\
\hline Present study & 2007 & $\begin{array}{l}\text { Bangladeshi Bengali adult } \\
\text { male cadavers }\end{array}$ & 56 & $\begin{array}{l}\text { Overallł external diameter } \\
\text { of appendix }\end{array}$ & $\begin{array}{l}0.32-0.83 \\
(0.48) \mathrm{cm}\end{array}$ \\
\hline Chowdhury [24] & 1993 & $\begin{array}{l}\text { Bangladeshi cadavers } \\
\text { (aged } 5 \text { to } 70 \text { years) }\end{array}$ & $\begin{array}{l}\text { Males } 68 \\
\text { Females } 32\end{array}$ & $\begin{array}{l}\text { External diameter of } \\
\text { appendix }\end{array}$ & $\begin{array}{l}0.3-1.1(064) \mathrm{cm} \\
0.3-1.0(0.55) \mathrm{cm}\end{array}$ \\
\hline Solanke [25] & 1970 & Nigerian children and adults & & $\begin{array}{l}\text { External diameter of } \\
\text { appendix }\end{array}$ & $(0.6) \mathrm{cm}$ \\
\hline $\begin{array}{l}\text { Davis and } \\
\text { Robinson's study } \\
\text { cited by Collins [30] }\end{array}$ & 1924 & & & $\begin{array}{l}\text { External diameter of } \\
\text { appendix }\end{array}$ & (0.6) $\mathrm{cm}$ \\
\hline
\end{tabular}

*Where results from both males and females were provided separately in the literature, only the results in the males are shown except those from Chowdhury [24], where combined results have been provided; this table shows the combined results for both males and females

Katzarski and Dutta [27] worked on the appendices of 132 Ghanaian cadavers, 95 males and 37 females. The age ranged from 4 to 80 years in males and 5 to 71 years in females. Katzarski et al. [28] worked on the appendices of 103 Zambian cadavers, 73 men and 30 women. Their ages ranged from 18 to 80 years. Maisel [14] worked on the appendices of 100 fetuses of 250 to 300 C: R length (aged
30 to 40 weeks) and 300 adult autopsied cadavers of South Africa; 103 were colored, 77 Bantus (Negros) and 130 Whites. Malas et al. [23] worked on the appendices of 80 Turkish fetuses (40 males and 40 females) whose gestational age was between 10 and 40 weeks. Ndoye et al. [29] worked on the appendices of fresh native cadavers (62 men and 18 women) with a mean age of 36 years (the 
age ranging between 16 and 78 years). Shugaba et al. [41] worked on the appendices of two Nigerians, one aged 24 years and the other 32 years in Nigeria. Solanke [25] worked on the appendices of 203 Nigerian cadavers. Among them 125 were children and adults and 78 were perinates (stillbirths and deaths within $24 \mathrm{~h}$ of birth). Wakeley [13] worked on the appendices of 10000 cases. No other details of the population have been provided.

Wakeley [13] tried to explain the commoner of the retrocaecal caecum during development undergoes helicoidal torsion whereby the appendicocaecal junction is displaced leftwards, upwards and backwards [28]. Katzarski et al. [28] reported that the retrocaecal position occurred in more than half of 882 infants. Katzarski et al. [28] pointed at the possibility that the high frequency of pelvic position among Ghanaian and Zambians represents a racial feature and may be one of the factors responsible for the recorded rarity of appendicitis among Africans [20]. Katzarski and Dutta [27] thought that in the pelvic position the blood vessels of the appendix are free from pressure, whereas in retrocaecal and retrocolic positions they could be compressed or kinked by the caecum or the ascending colon. So, when the appendix is inflamed the surgeons most commonly find it in the retrocaecal or retrocolic positions which might give it an inadequate blood supply [19].

Among the acute abdomen among Bugandans in Uganda only $1.7 \%$ were inflammatory lesions and $93 \%$ were obstructed lesions while in Britain $86.3 \%$ were inflammatory and $12.3 \%$ were obstructed [28]. Presentations of appendicitis are related to its position. For example, as the retrocaecal appendix does not touch the anterior abdominal wall the pain remains less intense and poorly localized, abdominal tenderness is minimal and may be elicited in the right flank. The psoas sign may be positive. On the other hand, a pelvic appendicitis causes pain in the lower abdomen with an urge to urinate and defecate [28, 37]. Various authors have related the variation in the anterior abdominal position to surgical complexity, history and profile of the appendix [35-42]. A similar kind of study including complexity, history and profile has been carried out recently but unfortunately it is on histology specific age adjusted ovarian cancer incidence [31]. Malas et al. [23] found most of the male appendices in subcaecal position and most of the female appendices in the retrocaecal position. Ajmani and Ajmani [32] reported that the retrocaecal and retrocolic positions of the appendix were by far the commonest (58\%) and consider that the prevalence of the retrocaecal and retrocolic position of the appendix may partly explain the incidence of appendicitis.
In the present study, most of the mesoappendices (about 63\%) failed to reach the respective appendix tips. Similar were the findings by Golalipour et al. [26]. Failure of the mesoappendix to reach the tip probably reduces the vascularization of the tip of the organs, making it more liable to become gangrenous and hence undergo early perforation during inflammation [26]. Malas et al. [23] stated that the attachment length of the meso-appendix could be of significant importance in clinical appendicitis since Ajmani and Ajmani [32] and Solanke [25] also stated that the features of the meso-appendix are important in the evaluation of appendicitis cases. There is no uniformity of results among workers. The distance between the base of the appendix and the ileocaecal junction varied from $1.9 \mathrm{~cm}$ to $3.8 \mathrm{~cm}$, as shown in Table II. In about $95 \%$ of the subjects, the distance varied between $2.00 \mathrm{~cm}$ and $3.99 \mathrm{~cm}$ (Figure 8). The greatest length of the appendix was found in the fourth decade of life and its mean length was found in the second decade of life. Average length as given by various authors varies from $7.5 \mathrm{~cm}$ to $11.5 \mathrm{~cm}$ (mean of average $8.7 \mathrm{~cm}$ ). The external diameter does not always show a tendency to decrease gradually from the base to the tip [42]. There was a statistically significant correlation between the diameter of the appendix and increasing age, the appendix becoming narrower with age [32]. A study in Southampton showed that acute appendicitis is most common in the $10-19$ year old group and appendicitis is rare over 50 years of age [33]. Length of vermiform appendix decreases gradually with increasing age [36].

Type of food is also an important factor that may influence the occurrence of appendicitis in different races of people. Burkitt and Trowell cited by Black [43] point out that communities with a high fiber diet have a low incidence of appendicitis, while those consuming a Western style diet, low in fiber and high in refined carbohydrates, have a higher incidence. Confirmation of their theory is provided by the difference in the incidence of appendicitis between British and Indian troops in India during the period of 1936-1947. Appendicitis was 4-6 times more common in the British than in the Indian troops. In the same period, the basic ration for Indian troops contained one third the amount of animal protein and three times as much high fiber foods as that of British soldiers in India [34]. In South Africa urban Black Africans continue to have a very low incidence of appendicitis in spite of the fact that their dietary intake of fiber is lower than that of the urban white population. Clearly then, there may be factors other than the level of fiber intake in determining the incidence of acute appendicitis [34].

It can be concluded that the factors that influence appendicitis may be the different macroscop- 
ic variables of the appendix, may be the diet of the people and the age of the people. Although there are no proper data available, observation shows that in Bangladesh the occurrence of appendicitis is more common in the middle and high income group of people who have a diet of low fiber intake than the low income group of people who have a diet of high fiber food. Finally, it may be concluded that the retrocaecal and retrocolic position of the appendix and failure of the meso-appendix to reach the tip are important in the evaluation of appendicitis performed in this study. An appropriate anatomical knowledge about vermiform appendix is important for surgeons, pathologists and other physicians for proper diagnosis and management of appendicitis and carcinoma [35-36].

Suggestions for further studies:

A) As our study scope was based on males, further studies in the female population may be undertaken as a rational extension of the present study.

B) The mode of the arterial study to the appendix could be an interesting topic for research.

C) The pre-operative, peri-operative and ultrasonographic features may be used to study appendicular features in different age groups to establish the age changes in the appendix.

\section{Acknowledgments}

It is our pleasure to express gratitude to Dr. Ishtiak Mannan, Gender and Reproductive Health Specialist, ICDDR, B for the statistical contribution and the Department of Forensic Medicine, Dhaka Medical College for supplying the specimens for the study. Special thanks to the anonymous referees and Editor-in-Chief for their valuable comments to raise the study to a higher standard.

\section{References}

1. Theobald D. The vestigiality of the human vermiform appendix [online]. Updated on February 3, 2005. The Talk Origins Archive.

2. Stein PL, Rowe BM. Physical anthropology. $8^{\text {th }}$ ed. McGrawHill, Boston 2003; 12-29.

3. Sanudo JR, Vasquez R, Puerta J. Meaning and clinical interest of the anatomical variation in the $21^{\text {st }}$ century. Editorial. Euro J Anat 2003; 7: 1-3.

4. Moore KL. Clinically oriented anatomy. $3^{\text {rd }}$ ed. Williams and Wilkins's, Baltimore 1992; 203-5.

5. Khorshid F. Preclinical evaluation of PM 701 in experimental animals. Int J Pharm 2008; 4: 443-51.

6. Chellaram C, Anand TP, Shailaja NR, Kesavan D. Herbicidal effects of marine animal, Trochus tentorium from gulf of Mannar, Southeastern India. A J Anim Vet Adv 2012; 7 : 250-5.

7. Latshaw D. Histology provides the best diagnosis of tibial growth plate defects caused by nutrition. J Anim Vet Adv 2006; 5: 315-21.

8. Chellaram C, Anand TP, Shailaja NR, Kesavan D. Herbicidal effects of marine animal, Trochus tentorium from gulf of
Mannar, Southeastern India. A J Anim Vet Adv 2012; 7 : 250-5.

9. De Garis CF. Topography and development of the cecumappendix. Ann Surg 1941; 113: 540-99.

10. Glover JW. The human vermiform appendix. TJ Archive 1988; 3: 31-8.

11. McQuaid KR. Alimentary. In: Tierney Jr LM, Mcphee SJ, Papadakis MA (eds.) Current medical diagnosis and treatment: adult ambulatory and impatient management. 41 ${ }^{\text {st }}$ ed. McGrow-Hill, New York 2002; 641.

12. Bannister LH. Alimentary systems. Gray's anatomy: the anatomical basis of medicine and surgery. $38^{\text {th }} \mathrm{ed}$. Williams PL. Churchill Livingstone, Edinburgh 1995; 1683-812.

13. Wakeley CPG. The position of the vermiform appendix as ascertained by an analysis of 10000 cases. J Anat 1933; 67: 277-83.

14. Maisel $H$. The position of the human vermiform appendix in fetal and adult age groups. Anat Rec 1960; 136: 385-91.

15. Buschard K, Kjaeldgaard A. Investigation and analysis of the position, fixation, length and embryology of the vermiform appendix. Acta Chir Scand Soc 1973; 139: 293-8.

16. Russel RCG, Williams NS, Bulstrode CJK. Bailey and Love's short practice of surgery. $24^{\text {th }}$ ed. Hodder Arnold, London 2004; 1103-6.

17. Mervat IK, Lobna A. Alzheimer's disease: current status of etiopathogenesis and therapeutic strategies. Pak J Bio Sci 2011; 14: 257-2.

18. Rahman AA, Gafur MA, Islam E, Anwar-ul-Islam M, Chowdhury AU. Sub-acute toxicity studies of a metabolite of Streptomyces species. Pak J Bio Sci 2002; 5: 1067-9.

19. Fevzi U, Ekrem E, Sinan S, Sak O. Morphology of the reproductive tract and ovariole histology of apanteles galleriae (Hymenoptera: Braconidae) reared on two host species. Pak J Bio Sci 2003; 6: 1389-95.

20. Snell RS. Clinical anatomy. $7^{\text {th }}$ ed. Lippincott Williams and Wilkins, Philadelphia 2004; 213-5.

21. Borley NR. Gray's anatomy; the anatomical basis of clinical practice. 39th ed. Churchill Livingstone, Edinburgh 2005; 1095-395.

22. Dymock RB. Pathological changes in the appendix: a review of 1000 cases. Pathology 1977; 9: 331-9.

23. Malas MA, Sulak O, Gokeimen A, Sari A. Development of the vermiform appendix during the fetal period. Surg Radio Anat 2004; 26: 202-7.

24. Chowdhury GMI. Anatomical study of human vermiform appendix in Bangladesh. Thesis (M Phil). Institute of Postgraduate Medicine and Research, University of Dhaka, Bangladesh 1993.

25. Solanke TF. The position, length and content of the vermiform appendix in Nigerians. Br J Surg 1970; 57: 100-2.

26. Golalipour MJ, Arya B, Azarhoosh R, Jahanshahi M. Anatomical variations of vermiform appendix in south-east Caspian Sea (Jordan-Iran). J Anat Soc India 2003; 52: 141-3.

27. Katzarski M, Dutta CR. The vermiform appendix in Ghanaians. Ghana Med J 1991; 4: 96-9.

28. Katzarski M, Rao UKG, Brady K. Blood supply and position of the vermiform appendix in Zambians. Med J Zambia 1979; 13: 32-4.

29. Ndoye JMN, Ndiaya A, Ndiaye A, Dia A, Fall B, Diop M. Cadaver topography and morphometry of the vermiform appendix. Surg Radio Anat 2005; 24: 363-5.

30. Collins DC. The length and position of the vermiform appendix: a study of 4,680 specimens. Ann Surg 1932; 96: 1044-8.

31. Fisher RE. The primate appendix. Anatomical Records. New Anatomist 2000; 261: 228-36. 
32. Ajmani ML, Ajmani K. The position, length and arterial supply of vermiform appendix. Anatomischer Anzeiger 1983; 153: 369-74.

33. Andreou P, Blains S, du Andboulay CEH. A histopathological study of the appendix at autopsy and after surgical resection. Histopathology 1990; 17: 427-31.

34. Rahman M, Khalil M, Khalil M. Length of human vermiform appendix in Bangladeshi people. J Bang Soc Physiol 2007; 2: $13-6$.

35. Modarres GM, Fariba B, Zamani F, Zamani N. Frequency of different types of ovarian cancer in Vali-e-Asr Hospital 2001-2003. Pak J Bio Sci 2007; 10: 3026-8.

36. Emre AU, Oge T, Bulent HU, et al. Adenocarcinoid tumor in a patient with familial Mediterranean fever operated for perforated appendicitis. Int J Can Res 2007; 3: 196-200.

37. Meamar AR, Ahady N, Falakimoghaddam MH, Safari MR, Kia EB. Concomitant infection of Appendix with Taenia and Enterobius vermicularis. J Med Sci 2006; 6: 38-40.

38. Naghshvar F, Torabizadeh Zh, Haghgoo A, Ghahremani M. Endometriosis of the Appendix presenting as acute appendicitis: a case report. Res J Bio Sci 2008; 3: 658-9.

39. Piechota M, Banach M, Jacoń A, Rysz J. How can we decrease mortality in surgery units? Arch Med Sci 2007; 3: 367-75.

40. Mederos R, Danielpour P, Christopher M, et al. Goblet Cell Carcinoid (GCC) tumors of the appendix: report of two cases and a short review of the literature. Surg J 2007; 2 33-6.

41. Shugaba Al, Umar MBT, Singh SP. Histomorphometric profile of the human vermiform appendix. I Med Sci 2006; 6: 445-51.

42. Paul UK, Naushaba H, Alam J. Length of vermiform appendix : a postmortem study. Bangladesh Journal of Anatomy 2011; 9: 10-2.

43. Blake J. Acute appendicitis in Japanese soldiers in Burma: support for the "fibre" theory. Gut 2002; 51: 297. 